\title{
Inheritance of soybean resistance to brown spot (Septoria glycines) in early greenhouse assessments
}

\author{
Renata Jung ; José Francisco Ferraz de Toledo*2 and Carlos Alberto Arrabal Arias ${ }^{2}$ \\ ${ }^{1}$ Departamento de Biologia da Universidade Estadual de Londrina (UEL), Caixa Postal 6001, CEP 86051-990, Londrina, \\ PR, Brazil; ${ }^{2}$ Empresa Brasileira de Pesquisa Agropecuária (EMBRAPA), Centro Nacional de Pesquisa de Soja (Embrapa \\ Soja), Caixa Postal 231, CEP 86001-970 Londrina, PR, Brazil. (* Corresponding Author. E-mail: toledo@cnpso.embrapa.br)
}

\begin{abstract}
Brown spot disease occurs at the end of the soybean (Glycine max (L.) Merrill) cycle in all cropping regions in Brazil. Under severe conditions, end-of-cycle leaf diseases can reduce crop yield by over $20 \%$. Although the development of resistant cultivars is the most efficient and economical way of disease control, little is known about the genetic mechanism controlling soybean resistance to brown spot. The objective of this study was to investigate the inheritance of resistance to this disease at an early stage (V3/V4) of plant development. The genotypes used were the FT-2 and Davis cultivars, considered resistant and susceptible, respectively, and the $\mathrm{F}_{2: 3}$ generation derived from their cross. The experiment was carried out in a greenhouse in a completely randomized design, including 20 plants from each parent and five plants from each $116 \mathrm{~F}_{2: 3}$ progenies. The soybean plants were inoculated at the V3/V4 stage and assessed for infection level on the $1^{\text {st }}, 2^{\text {nd }}$ and $3^{\text {rd }}$ leaves at 12, 19 and 26 days after inoculation. The greater susceptibility of Davis compared to FT-2 was confirmed. The $\mathrm{F}_{2: 3}$ generation presented reaction to brown spot infection intermediate to the parents. $\mathrm{F}_{2: 3}$ based broad sense heritability was predominantly of average magnitude indicating that in spite of the complexity of the trait, with high environmental influence, it is possible to obtain responses to early selection for brown spot resistance under greenhouse conditions when progenies are assessed.
\end{abstract}

KEY WORDS: Plant breeding, genotype x environment interaction, genetic resistance.

\section{INTRODUCTION}

Currently, soybean (Glycine max (L.) Merrill) is the most important oil crop in the world, accounting for $52 \%$ of the world production. Soybean production in Brazil has increased $29 \%$ in the last ten years moving from 24 million to 31 million tons between the $1988 / 89$ and $1998 / 99$ seasons. This increase in production is due to a significant increase in yield from $1,940 \mathrm{~kg} / \mathrm{ha}$ in $1988 / 89$ to $2,360 \mathrm{~kg} / \mathrm{ha}$ in $1998 /$ 99 , while the cultivated area increased only from 12.2 to 13 million hectares in the same period. Brazil is considered the second world soybean producer (Embrapa, 2000a).

Soybean yield in Brazil has increased yearly because of the new technologies and practices available in agriculture. Great technological advances have occurred, both in the improvement of cropping conditions and in the genetic potential of cultivars.

The new cultivars are developed to be highly productive and stable to the environmental variations for which they are indicated. The introduction of genetic resistance to disease is today one of the most important factors that ensures the stability of these cultivars. It is also, the most efficient and economic method of disease control easily assimilated by farmers (Embrapa, 2000b).

Disease occurrence in soybean fields has increased in the last 10 to 15 years causing significant yield losses. Usually, rapid responses from research towards the development and application of control techniques have helped minimize yield losses. Incorporating resistance genes into cultivars quickly solved problems with important diseases such as frogeye leaf spot and stem canker. It was a fast process because of their relatively simple genetic control and of the development of efficient assessment methods.

Yield losses caused by a disease complex at the end of the soybean crop cycle have worsened recently. These diseases are disseminated in all Brazilian soybean cropping regions, which differ only in disease severity. Brown spot, caused by the Septoria glycines fungus, is perhaps the main end-of-cycle disease and is disseminated throughout the regions. 
The complexity of the genetic control and environmental effects on this disease has prevented an accurate assessment of the level of losses that can be attributed to it. Although imprecise, estimates indicate that the losses are relatively high and vary greatly according to the predominant climate of a region in the year of assessment and the cultivar. There is genetic variability to be exploited, but the complex genetic control has required great research effort to develop efficient and accurate assessment methods of the symptoms and damage caused. Knowledge of the genetic control of resistance and the development of quick and efficient methods for soybean genotype selection will permit the incorporation of resistance genes in the most adapted and productive cultivars in the different regions of the country.

Early assessment carried out at the initial soybean growth stages has enabled screening among susceptible and resistant genotypes. The study of the inheritable portion of the resistance trait and its interaction with the environment, in early greenhouse assessments, may provide very useful information for breeding. Thus, this study was carried out to investigate the inheritance of soybean resistance to brown spot using the FT-2 cultivar at three different early development stages.

\section{MATERIAL AND METHODS}

The FT-2 (selection in IAS-5, derived from the Hill x D52-810 cross) and Davis (derived from the D49-2573 x N45-1497 cross) cultivars were used in this study. The FT-2 cultivar was considered resistant to brown spot in greenhouse and field assessments (Yorinori 1987a, 1987b). Davis has been used as susceptibility control to brown spot in experiments and was also considered susceptible in the field assessments.

Twenty individuals from each parent and $116 \mathrm{~F}_{2: 3}$ progenies each represented by five individuals were included in a completely randomized greenhouse experiment at Embrapa Soybean, in November 1999 and March 2000. Each experimental unit was a single plant of the materials tested. One susceptibility control (cv. Davis) was sown in each pot as a check for microenvironmental variation. Individual plants were phenotypically assessed for reaction to Septoria glycines and the mean of each progeny was obtained.

A Septoria glycines isolate from the Phytopathology
Laboratory at Embrapa Soybean was used for inoculation. It was then replicated in test tubes with culture medium, transferred to Petri dishes for sporulation and used for suspension preparation at an inoculum concentration of approximately $6 \times 10^{6}$ conidia/ml. Inoculation was performed with a manual spray, applying the equivalent of $4 \mathrm{ml}$ of suspension to each plant at the V3/V4 stage (Fehr et al., 1971).

Assessments were made as the brown spot symptoms appeared on the first, second and third trifoliate leaves, noting the level of infection (NI) of the disease on the leaf, on a scale of scores from zero to ten. The first three trifoliate leaves of the parents and $\mathrm{F}_{2: 3}$ progeny plants were assessed at three occasions (12, 19 and 26 days after inoculation).

Analyses of variance were performed and means and variances obtained for each stage and generation. The heritability of resistance was calculated from the disease incidence in each trifoliate leaf, in the average of the first two and on the average of the three leaves.

The complete data set was used to obtain a joint analysis of variance of the parents to verify the effects of genotypes (parents), leaves, genotypes x leaves interaction, assessments, genotypes $\mathrm{x}$ assessment interactions, leaf $\mathrm{x}$ assessment interaction and the parents $\mathrm{x}$ leaves $\mathrm{x}$ assessments interaction.

The model for this analysis is determined by:

$$
\begin{aligned}
& \mathrm{Y}_{\mathrm{ijk}}=\mathrm{m}+\mathrm{p}_{\mathrm{i}}+\mathrm{f}_{\mathrm{j}}+(\mathrm{pf})_{\mathrm{ij}}+\mathrm{a}_{\mathrm{k}}+(\mathrm{pa})_{\mathrm{i} \mathrm{k}}+(\mathrm{fa})_{\mathrm{jk}}+(\mathrm{pfa})_{\mathrm{ijk}} \\
& +\mathrm{e}_{\mathrm{l}(\mathrm{j} \mathrm{jk})}
\end{aligned}
$$

Where $Y_{i j k}$ corresponds to the adjusted infection mean of the i-th parent (or progeny), of the j-th leaf and kth assessment, $m$ to the general mean of the experiment, $p_{i}$ to the $i$-th parents effect, $f_{j}$ to the effect of the $\mathrm{j}$-th leaf, $(\mathrm{pf})_{\mathrm{ij}}$ to the effect of the interaction between the $i$-th parent and the $j$-th leaf, $a_{k}$ to the effect of the k-th assessment, (pa) $)_{\mathrm{ik}}$ to the effect of the interaction between the i-th parent and the k-th assessment, (fa) ${ }_{j k}$ to the effect of the interaction between the $\mathrm{j}$-th leaf and the k-th assessment, $(\mathrm{pfa})_{\mathrm{ijk}}$ to the effect of the triple interaction between the $\mathrm{i}$-th parent, $\mathrm{j}$-th leaf and $\mathrm{k}$-th assessment and $\mathrm{e}_{1(\mathrm{ijk})}$ is the experimental error. The parents, leaf and assessment effects were considered fixed.

All assessment and trifoliate leaf data were used again to perform a joint analysis of variance for the $\mathrm{F}_{3}$ progenies to verify the significance of progeny, leaf, progeny $\mathrm{x}$ leaf interaction, assessment, progeny $\mathrm{x}$ assessment interaction, leaf $\mathrm{x}$ assessment interaction and the progeny $\mathrm{x}$ leaf interaction and assessment 
effects. The statistical model for this analysis is similar to that for the joint analysis of variance of the parents. In this case, the assessment and leaf effects were considered fixed and progeny random.

Broad sense heritability was calculated from the genetic and environmental components of the F3 progeny means according to Mather and Jinks (1984):

$\mathrm{h}^{2}=\mathrm{s}_{\mathrm{b}}^{2} / \mathrm{s}_{\mathrm{b}}^{2}+\left(\mathrm{s}^{2}{ }_{\mathrm{w}} / \mathrm{n}_{2}\right)$

Where $\mathrm{h}^{2}$ is the broad sense heritability based on the $\mathrm{F} 3$ progeny means, $\mathrm{s}_{\mathrm{b}}{ }_{\mathrm{b}}$ is the genetic variance between $\mathrm{F}_{3}$ progenies, $\mathrm{s}_{\mathrm{w}}^{2}$ is the variance within $\mathrm{F} 3$ progenies and $\mathrm{n} 2$ is the harmonic mean of the number of individuals in each $\mathrm{F} 3$ progeny.

\section{RESULTS AND DISCUSSION}

According to the results of the analysis of variance in Table 1, which was performed on all data obtained from the three trifoliate leaves and three assessments of the parental generations, the effects of parents and leaves were significant for the three assessments. The $43.07 \%$ coefficient of variation value was considered acceptable for this type of experiment.

Differences among parents were significant at the $1 \%$ level of probability $(\mathrm{P} \leq 0.01)$ as expected, as they were selected for their divergent expression of the trait. The differences among leaves were also significant in all assessments, at $\mathrm{P} \leq 0.01$ for the $1^{\text {st }}$ and $3^{\text {rd }}$ assessments and at the $5 \%$ level of probability $(\mathrm{P} \leq 0.05)$ for the $2^{\text {nd }}$ assessment.

The parent $x$ leaf interaction was significant in the first and second assessments, but not in the third. As this interaction was significant at $\mathrm{P} \leq 0.05$ in the first and second assessment but was not in the third, there is an indication that the level of divergence among the parents was not strongly influenced by the leaf assessed. This is important for selection purposes, as a large interaction effect would make less clear the differences among the chosen cultivars, which is the trait that ultimately interests the breeder.

According to the results of the joint analysis of variance of the parents (Table 2), the main effects of parents, leaves and assessments, and the parent $\mathrm{x}$ assessment and leaves $\mathrm{x}$ assessment interactions were significant. The interactions parents $\mathrm{x}$ leaves and parents $\mathrm{x}$ leaves $\mathrm{x}$ evaluations were not significant.

Differences among parents were expected, as previously mentioned, because they are divergent for the trait. The high significance $(\mathrm{P} \leq 0.01)$ of the leaf effect in this experiment is probably due to the disease development generally from the older leaf to the younger ones, that is, from the first trifoliate leaf to the third. The parent $x$ leaf interaction was not significant, indicating that the disease progression in the leaves was similar in the susceptible and resistant parent and that differences between parents did not depend on the trifoliate leaf assessed.

Differences among assessments $(\mathrm{P} \leq 0.01)$ were also expected, as they were carried out at three different times, with a tendency for the disease to evolve from the first to the third assessment. The choice of the best period of assessment was important since the parents $\mathrm{x}$ assessment interaction was significant $(\mathrm{P} \leq 0.01)$, indicating that the assessments differ in terms of ability to differentiate between genotypes. The leaf $\mathrm{x}$ assessment interaction was significant $(\mathrm{P} \leq 0.01)$, showing that the differences among leaves changed with time. However, this interaction did not change the ranking among the analyzed cultivars, as indicated by the non-significant parent $\mathrm{x}$ leaf $\mathrm{x}$ assessment interaction. This may be due to the great dissimilarity between the FT-2 and Davis reactions. However, together with the non-significance of the parent $\mathrm{x}$ leaf interaction, it clearly suggested that choosing the best trifoliate leaf for disease assessment did not bring much advantage. The best assessment period was at 19 days and the best trifoliate leaf for

Table 1. Analyses of variance of the first, second and third evaluations of brown spot resistance in the parental generations. Data for infection levels in three assessed trifoliate leaves.

\begin{tabular}{|c|c|c|c|c|c|c|}
\hline \multirow[b]{2}{*}{ SV } & \multicolumn{2}{|c|}{$1^{\text {st }}$ Evaluation } & \multicolumn{2}{|c|}{$2^{\text {nd }}$ Evaluation } & \multicolumn{2}{|c|}{$3^{\text {rd }}$ Evaluation } \\
\hline & df & SS & df & SS & df & SS \\
\hline Parents (P) & 1 & $47.81^{2 /}$ & 1 & $282.67^{2 /}$ & 1 & $433.11^{2 /}$ \\
\hline Leaf $(F)$ & 2 & $10.25^{2 /}$ & 2 & $40.35^{1 /}$ & 2 & $63.91^{2 /}$ \\
\hline $\mathrm{P} \times \mathrm{F}$ & 2 & $6.12^{1 /}$ & 2 & $40.56^{1 /}$ & 2 & $7.35^{\mathrm{ns}}$ \\
\hline Exp error & 111 & 104.48 & 108 & 491.11 & 108 & 669.81 \\
\hline Total & 116 & & 113 & & 112 & \\
\hline
\end{tabular}


Table 2. Joint analysis of variance of brown spot resistance in three assessments of the parental generations. Data for infection levels in the three assessed trifoliate leaves.

\begin{tabular}{lcc}
\hline SV & df & MS \\
\hline Parents (P) & 1 & $664.51^{1 /}$ \\
Leaves (F) & 2 & $28.67^{1 /}$ \\
P x F & 2 & $10.58 \mathrm{~ns}$ \\
Evaluations (A) & 2 & $423.78^{1 /}$ \\
P x A & 2 & $52.85^{1 /}$ \\
F x A & 4 & $14.56^{1 /}$ \\
P x F x A & 4 & $8.22^{\mathrm{ns}}$ \\
Exp error & 327 & 3.87 \\
\hline Total & 344 & \\
\hline
\end{tabular}

assessment was the second (Table 4). Under these conditions, greater differences were detected among the parents. The estimated heritability was of average magnitude, approximately $40 \%$, indicating that it is possible to obtain responses to selection for resistance to brown spot.

According to the results of the joint analysis of variance of the $\mathrm{F}_{2: 3}$ progenies (Table 3), significant differences were observed for progeny, leaves, the progeny $\mathrm{x}$ leaves interaction, assessments, progeny $\mathrm{x}$ assessments interaction and leaves $\mathrm{x}$ assessment interaction $(\mathrm{P}<0,01)$ effects.

Differences among progeny were also expected, as they stem from divergent parents for the trait and the $\mathrm{F}_{2: 3}$ progenies reflect this variability.

The effect of leaves in the $F_{2: 3}$ progeny experiment, as in the experiment with the parents, was significant due to the quick evolution of the disease from the oldest leaf to the youngest, that is, from the first trifoliate leaf to the third. Physiologically it is known that the plant age, and consequently its trifoliate leaf age, is expressed by different metabolic activity (Yorinori, 1989).

Although the progeny $\mathrm{x}$ leaves interaction was significant, indicating that as different leaves were assessed there was variation in the degree of disease in the various progenies, its value was considered small and, coupled with a non-significant progenies $\mathrm{x}$ leaf $\mathrm{x}$ assessment interaction, it was taken as an indicator of non-occurrence of rank inversions of the $\mathrm{F}_{2: 3}$ progenies scores for the evaluated trait.

The assessment effect was significant as they were carried out at three different times, with a tendency for the disease to evolve from the first to the second assessment. As in the parent analysis, there is a possibility of choosing the assessment that best discriminates the difference among genotypes. The third assessment discriminated best among progeny means as indicated by the between progeny variance in Table 4.

The progeny $\mathrm{x}$ assessment interaction was significant, indicating that the assessments differed in terms of progeny screening capacity. The significance of the leaves $\mathrm{x}$ assessment interaction showed that the differences among leaves varied with time and that the choice of the best trifoliate leaf was important to assess the disease. However, the non-significance of the parent $\mathrm{x}$ leaf $\mathrm{x}$ assessment interaction and the absence of rank inversions suggested that these interactions poses no serious problems for the breeder.

Table 4 shows the mean, variances, degrees of freedom and broad sense heritability estimates for brown spot infection level in the first, second and third trifoliate leaves using the $\mathrm{F}_{2: 3}$ generation in the first, second and third assessment, respectively.

The data confirmed the greater susceptibility of Davis compared to FT-2 and showed that the F3 generation presented an intermediate mean for Septoria glycines infection.

Using data from similar assessments, Brogin (2001) adjusted genetic models to the means and variances of the parental (FT-2 and Davis), F2 and F3 generation and concluded that additive effects predominate in the genetic control of soybean resistance to brown spot. Still according to this author, heritability is substantially influenced by environment and is very low at individual plant level. On the other hand, the broad sense heritability, based on the means of $\mathrm{F}_{3: 2}$ progenies, ranged from $10.5 \%$ to $52 \%$ for different

Table 3. Joint analysis of variance of resistance to brown spot of three $\mathrm{F}_{3: 2}$ progeny assessments. Data for infection levels in three assessed trifoliate leaves.

\begin{tabular}{lcc}
\hline SV & df & MS \\
\hline Progenies (P) & 115 & $23.92^{1 /}$ \\
Leaves (F) & 2 & $652.90^{1 /}$ \\
P x F & 230 & $8.33^{1 /}$ \\
Evaluations (A) & 2 & $7177.93^{1 /}$ \\
P x A & 230 & $5.44^{1 /}$ \\
F x A & 4 & $446.04^{1 /}$ \\
P x F x A & 460 & $2.28^{\text {ns }}$ \\
Exp error & 4104 & 4.21 \\
\hline Total & 5147 & \\
\hline
\end{tabular}


Table 4. Degrees of freedom (df), means ( $\bar{x})$, variances (var) and heritability estimates $\left(h^{2 \%} \%\right)$ of resistance to brown spot in the parental generations and $\mathrm{F}_{3: 2}$ progenies. Data on the first, second and third assessments of infection level in the first, second and third trifoliate leaves.

\begin{tabular}{|c|c|c|c|c|c|c|c|c|c|}
\hline \multirow{3}{*}{ Generation } & \multicolumn{9}{|c|}{$1^{\text {st }}$ Evaluation } \\
\hline & \multicolumn{3}{|c|}{ 1st Trifoliate } & \multicolumn{3}{|c|}{ 2nd Trifoliate } & \multicolumn{3}{|c|}{ 3rd Trifoliate } \\
\hline & $\mathrm{df}$ & $\overline{\bar{x}}$ & var & $\mathrm{df}$ & $\overline{\mathrm{x}}$ & var & $\mathrm{df}$ & $\overline{\mathrm{x}}$ & var \\
\hline FT-2 & 19 & 0.85 & 0.24 & 19 & 0.90 & 0.52 & 19 & 1.15 & 0.66 \\
\hline Davis & 18 & 1.53 & 0.82 & 18 & 2.68 & 3.12 & 18 & 2.53 & 0.37 \\
\hline $\mathrm{F}_{3}(\mathrm{FT}-2 \times$ Davis $)$ & 521 & & 0.72 & 521 & & 0.88 & 521 & & 1.15 \\
\hline Between progeny $\left(\delta^{2} \mathrm{w}+\mathrm{n}_{2} \delta^{2} \mathrm{~b}\right)$ & 115 & 0.94 & 0.79 & 115 & 1.63 & 1.18 & 115 & 1.75 & 1.57 \\
\hline Within progeny $\left(\delta^{2} \mathrm{w}\right)$ & 456 & & 0.71 & 456 & & 0.81 & 456 & & 1.05 \\
\hline \multirow[t]{2}{*}{$\hat{\mathrm{h}}^{2}$} & \multicolumn{3}{|c|}{12.40} & \multicolumn{3}{|c|}{33.29} & \multicolumn{3}{|c|}{34.40} \\
\hline & \multicolumn{9}{|c|}{$2^{\text {nd }}$ Evaluation } \\
\hline \multirow[t]{2}{*}{ Generation } & \multicolumn{3}{|c|}{ 1st Trifoliate } & \multicolumn{3}{|c|}{ 2nd Trifoliate } & \multicolumn{3}{|c|}{ 3rd Trifoliate } \\
\hline & $\mathrm{df}$ & $\overline{\mathrm{x}}$ & var & $\mathrm{df}$ & $\overline{\mathrm{x}}$ & var & $\mathrm{df}$ & $\overline{\mathrm{x}}$ & var \\
\hline FT-2 & 19 & 1.75 & 2.41 & 19 & 1.50 & 1.11 & 19 & 1.40 & 0.36 \\
\hline Davis & 17 & 4.22 & 8.18 & 17 & 6.33 & 12.12 & 17 & 3.56 & 0.49 \\
\hline $\mathrm{F}_{3}(\mathrm{FT}-2 \times$ Davis $)$ & 521 & & 5.22 & 521 & & 5.54 & 521 & & 3.85 \\
\hline Between progeny $\left(\delta^{2} \mathrm{w}+\mathrm{n}_{2} \delta^{2} \mathrm{~b}\right)$ & 115 & 3.34 & 7.41 & 115 & 3.65 & 8.25 & 115 & 2.4 & 4.71 \\
\hline Within progeny $\left(\delta^{2} \mathrm{w}\right)$ & 456 & & 4.66 & 456 & & 4.85 & 456 & & 3.63 \\
\hline \multirow[t]{2}{*}{$\hat{\mathrm{h}}^{2}$} & \multicolumn{3}{|c|}{37.11} & \multicolumn{3}{|c|}{41.00} & \multicolumn{3}{|c|}{22.93} \\
\hline & \multirow{2}{*}{\multicolumn{6}{|c|}{$\frac{\text { 3rd Evaluation }}{\text { 2nd Trifoliate }}$}} & & & \\
\hline \multirow{2}{*}{ Generation } & & & & & & & \multicolumn{3}{|c|}{ 3rd Trifoliate } \\
\hline & $\mathrm{df}$ & $\overline{\mathrm{x}}$ & var & $\mathrm{df}$ & $\bar{x}$ & var & $\mathrm{df}$ & $\bar{x}$ & var \\
\hline FT-2 & 19 & 4.20 & 6.80 & 19 & 4.15 & 6.98 & 19 & 2.05 & 1.10 \\
\hline Davis & 17 & 7.67 & 6.35 & 17 & 7.78 & 8.07 & 17 & 6.67 & 8.35 \\
\hline $\mathrm{F}_{3}(\mathrm{FT}-2 \times$ Davis $)$ & 521 & & 9.78 & 521 & & 9.01 & 521 & & 6.60 \\
\hline Between progeny $\left(\delta^{2} \mathrm{w}+\mathrm{n}_{2} \delta^{2} \mathrm{~b}\right)$ & 115 & 6.45 & 14.58 & 115 & 6.26 & 15.12 & 115 & 3.85 & 7.41 \\
\hline Within progeny $\left(\delta^{2} \mathrm{w}\right)$ & 456 & & 8.56 & 456 & & 7.44 & 456 & & 6.39 \\
\hline$\hat{\mathrm{h}}^{2}$ & \multicolumn{3}{|c|}{41.42} & \multicolumn{3}{|c|}{50.65} & \multicolumn{3}{|c|}{13.91} \\
\hline
\end{tabular}

assessment periods, indicating that it is possible to obtain responses to selection for brown spot resistance.

In this study, the broad sense heritability, based on $\mathrm{F}_{3: 2}$ progeny means in the first, second and third assessments were $12.40 \%, 37.11 \%$ and $41.52 \%$, respectively, for the first trifoliate leaf; $33.29 \%$, $41.00 \%$ and $50.65 \%$ for the second trifoliate leaf and $34.40 \%, 22.93 \%$ and $13.91 \%$ for the third trifoliate leaf (Table 4).

Broad sense heritability based on $\mathrm{F}_{3: 2}$ progeny means was considered predominantly of average magnitude $\left(30 \% \leq \mathrm{h}^{2} \leq 60 \%\right)$ indicating that the selection for resistance to brown spot could be performed in the initial segregant generations of a breeding program.

Brogin's (2001) observation that selection for resistance to brown spot should be carried out under controlled conditions in a greenhouse was confirmed by this study, as there was great environmental influence on the trait. In the experimental field, besides the environmental effects that hinder assessments, either by moisture alteration, temperature or number of spores for infection, there is also the presence of other diseases that mask the results. Therefore, the greenhouse ensures greater environmental control during the experiment as well as efficient genotype screening and selection.

The presence of the Davis control in each pot allowed the observation that the best time for leaf brown spot infection assessment, which was taken as the assessment time that best screened among genotypes (at 19 days for parents and 26 days for the $F_{3: 2}$ progenies), invariably corresponded to infection levels ranging from 6 to 8 in the control. This corroborates the observations of Yorinori (1989), and 
means that the assessment period can be adjusted to guarantee such condition.

\section{CONCLUSIONS}

Resistance to brown spot trait has polygenic control and is highly influenced by the environment.

Selection for resistance to brown spot should be carried out in a greenhouse because of the complexity of the trait and the environmental influence.

For breeding purposes selection can start at the $\mathrm{F}_{3: 2}$ generation based on progeny means to reduce the experimental error and the environmental effects on the trait. Broad sense heritability for the trait, based on $\mathrm{F}_{3: 2}$ progeny means of the FT-2 $\mathrm{x}$ Davis cross, is of average magnitude, indicating that response to selection for resistance to brown spot will be satisfactory.

\section{RESUMO}

Herança da resistência de soja à mancha-parda causada pelo fungo Septoria glycines em gerações precoces avaliadas em casa-de-vegetação

A doença mancha-parda causada pelo fungo (Septoria glycines) ocorre no final do ciclo de desenvolvimento da soja (Glycine max (L.) Merrill) em todas as regiões produtoras do Brasil. Sob condição de incidência severa a doença pode causar redução maior que $20 \%$ na produtividade. Embora o uso de cultivares resistentes seja o mais eficiente e econômico método de controle, pouco se conhece sobre o mecanismo genético de resistência à mancha-parda em soja. $\mathrm{O}$ principal objetivo deste trabalho é investigar a herança da resistência a esta doença nos estágios iniciais (V3V4) do desenvolvimento das plantas de soja. Os genótipos utilizados neste estudo foram as cultivares FT-2 e Davis, consideradas resistente e susceptível, respectivamente, e a geração $F_{2: 3}$ derivada do cruzamento entre elas. $\mathrm{O}$ experimento foi conduzido em casa-de-vegetação em um delineamento completamente casualizado incluindo 20 plantas de cada cultivar e cinco plantas de cada uma de 116 progênies $\mathrm{F}_{2: 3}$. As plantas foram inoculadas no estágio V3-V4 e acessadas quanto ao nível de doença nas $1^{\mathrm{a}}$, $2^{\mathrm{a}}$ e $3^{\mathrm{a}}$ folhas aos 12, 19 e 26 dias após a inoculação. A maior susceptibilidade de Davis em relação a FT2 foi confirmada. A geração $F_{2: 3}$ apresentou reação de resistência à mancha-parda intermediária à das cultivares. A herdabilidade no sentido amplo, obtida com base na geração $F_{2: 3}$, foi de média magnitude. Os resultados indicaram que, embora a característica possua herança genética complexa altamente influenciada pelo ambiente, é possível obter resposta para resistência à mancha-parda em seleção precoce realizada sobre progênies em casa-de-vegetação.

\section{REFERENCES}

Brogin, R. L. 2001. Controle genético da resistência da soja à mancha parda (Septoria glycines) M. S. Thesis. Universidade Estadual de Londrina, Londrina.

Embrapa. 2000a. A cultura da soja no Brasil. Embrapa Soja, Londrina. CD ROM

Embrapa. 2000b. Recomendações técnicas para a cultura na região central do Brasil 2000/01. Documentos, 146. Embrapa Soja, Londrina.

Fehr, W. R.; Caviness, C. E.; Butwood, D. T. and Pennington, J. S. 1971. Stage of development descriptions for soybeans, Glycine $\max$ (L.) Merrill. Crop Sci. 11:929-931.

Mather, K. and Jinks, J. L. 1984. Introdução à genética biométrica sociedade brasileira de genética. Sociedade Brasileira de genética, Riberão Preto.

Yorinori, J.T. 1987a. Avaliação do efeito das doenças de final de ciclo ao nível de lavoura. In: Embrapa. Resultados de Pesquisa de Soja 1985/86. Embrapa Soja, Londrina.

Yorinori, J.T. 1987b. Determinação do grau de tolerância a doenças de final de ciclo em cultivares de soja. p.208-210. In: Embrapa. Resultados de Pesquisa de Soja. 1985/86. Embrapa Soja, Londrina.

Yorinori, J. T. 1989. Efeito da idade da folha de soja sobre a infecção por Cercospora sojina. p. 405. In: Embrapa. Resultados de Pesquisa de Soja 1988/89 Embrapa Soja, Londrina.

Received: May 03, 2001; Accepted: December 11, 2001. 